\title{
Tracing connections: Kurdish women singers and the ambiguities of owning oral tradition
}

Marlene Schäfers

FWO [PEGASUS] ${ }^{2}$ Marie Skłodowska-Curie Fellow

Department of Conflict and Development Studies

Ghent University

While doing fieldwork with female Kurdish bards (dengbêjs) in the Eastern Anatolian region of Van in 2011/12, I was often struck by how my interlocutors could insist that a particular ballad (kilam) or folk song they knew belonged to them (Ev ya min e!) while at the same time explaining to me how the song in question had been sung by other people in the past, or how they had learned it from a particular relative or acquaintance, a radio broadcast or cassette tape. This volume focuses on the vibrancy of connection and exchange between different singer-poet traditions in Anatolia. My interlocutors, however, effectively disavowed certain connections as they asserted that a particular piece belonged to them (those connections, for example, that would regard the piece in question as part of an overarching, communally shared heritage) while simultaneously acknowledging others (including lines of genealogical transmission and apprenticeship). This paper seeks to unravel the ambiguous engagement with musical exchange and connection that comes to the fore in these instances. It does so by investigating how claims to ownership over musical traditions made by female dengbêjs work both with and against notions of collectively held cultural heritage as well as genealogical logics of tracing descent.

Simultaneously insisting on owning a folk song and acknowledging that same musical tradition to be practiced by others might seem paradoxical. In this chapter I argue, however, that such seemingly paradoxical statements are expressions of the friction that arises as different logics of reckoning relations rub against each other. In contemporary Turkish Kurdistan, we can observe how older genealogical ways of reckoning connections between oral traditions are being reconfigured through the 
logics of cultural property. The latter find expression, I suggest, both in claims to individual ownership over particular cultural artefacts and in the notion of a collectively held, overarching Kurdish cultural heritage. Dengbêjs, in particular, have come to be heralded as amongst the most important protagonists of this heritage. I argue that this has introduced a dynamic of commodification into the field of dengbêjî, which has rendered questions of owner- and authorship of genealogically transmitted and often anonymous oral traditions a nexus of debate, anxiety, and controversy. Gender, I moreover suggest, is one central fault line around which these contestations unfold in the Kurdish context.

More broadly, my aim in this chapter is to shed light onto how the logics of cultural property, in tandem with discourses of cultural heritage and multiculturalism, have come to reconfigure how members of Turkey's Kurdish community conceive of, relate to and perform their "culture." At the same time I also want to offer some reflections on the politics and poetics of making (and breaking) connections, as the theme that unites contributions to this volume. Anthropologist Marilyn Strathern (1996a) has argued that asserting intellectual ownership relies on what she terms "cutting the network." Within the logics of property, Strathern holds, claiming ownership over a cultural product requires disavowing or "cutting" links to a potentially infinite number of relations that might have contributed to the creation of a cultural artefact. Such acts of cutting are exercises as much in channelling forces of creativity as in forging communal genealogies by tracing roots and establishing descent. Cutting a network, in other words, always entails acts of inclusion and exclusion. As such, it is inherently political. Here, I seek to document how a number of Kurdish women singers are involved in the delicate work of handling relations including cutting some, while acknowledging others - and with what effects. Needless to say, as researchers we are equally involved in seeing, establishing, and denying relations and might well want to pause over how this involves us in the fashioning of networks, genealogies, and communities.

\section{Fantasies of homogeneity: Dengbêjs and Kurdish cultural heritage}

Before focusing in more detail on how the female dengbêjs I worked with engage in the forging and cutting of networks it will be useful to outline how dengbêjî, in the 
past a set of rather dispersed regional oral traditions, has come to be resignified as a central constituent of an ostensibly overarching Kurdish cultural heritage. Today, dengbêjs are routinely celebrated as perhaps the most paradigmatic representatives of authentic Kurdish culture and traditions. The intense interest in dengbêjs and their oral traditions is relatively recent, however, dating back only to the early 2000 s.

To be sure, dengbêjs and their oral traditions had already been discovered by Ottoman-Kurdish intellectuals of the early twentieth century in their attempts at delineating a Kurdish culture that would befit the nation they hoped to forge (Fuccaro, 2003: 206-209; Strohmeier, 2003: 151-154; Yüksel, 2010: 239-267). Their initiatives to collect and document Kurdish oral traditions and folklore crucially drew upon dengbêjs' repertoires, though mainly for the insights these provided into the Kurdish language, whose documentation and standardization was deemed instrumental for the forging of Kurdish national unity (Yüksel, 2010: 65; see also Klein, 2000: 16-17). The Kurdish political movement that emerged in Turkey over the course of the 1970s, by contrast, was much less enthralled with the oral traditions of singer-poets who had formed an integral element of Kurdish feudal and tribal society. Staunchly socialist, the movement regarded dengbêjs largely as symbols of the old order that the Kurdish people ought to overcome in the name of both social and political revolution (Scalbert-Yücel, 2009). The movement's cultural politics consequently encouraged protest music combining elements of Western rock music, socialist marches and Anatolian folk music rather than elderly men and women chanting (hi)stories of tribal warfare, blood feuds, and elopements (Aksoy, 2006; Blum and Hassanpour, 1996).

Beginning in the late 1990s and early 2000s this situation started to change as the result of several factors. One important element was the ideological reorientation of the PKK and the Kurdish movement more broadly after the arrest of Abdullah Öcalan in 1999, which entailed the embracement of a politics of identity focusing on the attainment of cultural and linguistic rights for Kurds in Turkey. This shift in the political arena coincided with a renewed interest in dengbêjî amongst Kurdish writers and intellectuals (Scalbert-Yücel, 2009). Central to the change in perception of dengbêjî has moreover been the role of Kurdish municipalities and cultural institutions like the Mesopotamia Cultural Centres (Navendên Çanda Mezopotamya, NÇM), which have since the early 2000s increasingly promoted dengbêjî through 
festivals and concerts, the opening of so-called Dengbêj Houses (Malên Dengbêjan) and other institutionalized cultural activities (see also Watts, 2010: 142-160).

As a result, dengbêjs enjoy unprecedented popularity today. Television programmes of various Kurdish and Turkish broadcasters regularly feature dengbêjî performances during entire evening shows, often in studio settings that seek to evoke the "authenticity" of the Kurdish village through artefacts like hand-woven carpets, clay pots, and oil lamps. Dengbêjî recordings also make up a sizeable proportion of the professionally distributed Kurdish music in Turkey and of the music that circulates outside the realm of copyright law, judging from the ubiquitous acoustic presence of dengbêjs' voices in both public and private spaces (cf. Reigle, 2013).

The revival of dengbêjî also has to be seen in the context of a global turn towards (multi)culturalist politics and the particular ways in which this has taken shape in Turkish Kurdistan. An important condition for the renewed interest in dengbêjî has thus been the turn to a politics of pluralism during the Justice and Development Party's (Adalet ve Kalkınma Partisi, AKP) first term in office (2002-2007), which granted greater cultural rights to Turkey's ethnic, religious, and linguistic minorities and eased restrictions on the public use of the Kurdish language. Arguably, however, this opening of the public sphere was tied to the imperative to depoliticize cultural content. The state granted public visibility to its minoritarian subjects only under the condition that they would not question well-rehearsed narratives of national history and belonging or the country's territorial integrity (Karaca, 2011: 158; Tambar, 2014). In the particular case of dengbêjî this has meant that the public performance of oral traditions that address legacies of state violence, displacement, and the ongoing war between Turkish state forces and the Kurdistan Workers' Party (Partiya Karkerên Kurdistanê, PKK) are routinely censored and legally prosecuted as instances of "terrorist propaganda" (Schäfers, 2015). This means that minoritarian voices in Turkey are able to emerge into the public only so long as they stay within the bounds of innocuous folklore that bolster rather than threaten the state's image as the patron of benevolent tolerance.

As a result, Kurdish cultural production is sharply divided over adhering to or defying state-imposed notions of folklore, culture, and politics. Yet what remains remarkably constant across divisions is a strong investment by actors in the Kurdish 
cultural field in the notion of one overarching Kurdish cultural heritage. "Kurdish culture" thus constitutes an established field of debate and intervention. This culture, moreover, is regularly described as being at acute risk of disappearance due to decades of state-enforced denial and assimilation, which prevented Kurdish cultural traditions from being lastingly recorded, documented, and archived. Much cultural activism today consequently focuses on conserving, promoting, and reviving Kurdish oral traditions in particular, as these are often regarded as the core of authentic Kurdish culture.

The idea that each ethnic or national community has its own distinctive culture is of course in many ways a distinctly modern one and, as scholars of heritage have pointed out, it has been central to the forging of the modern nation-state (Viejo-Rose, Isar, \& Anheier, 2011). Having "a culture" constitutes a crucial condition for being recognized as a distinct community with a justified claim towards political representation. Important for the purposes of my argument here is to note how this reification of cultural traditions as the marker of ethnic or national identity also entails the erasure of local and regional differences within such traditions. Nicolas Elias's (2016) research on cultural festivals in Turkey's Black Sea region shows, for example, how subtle local variations in lyrics, performance style, or instrumentalisation easily fall victim to the organization of the culture industry which demands widely recognizable tunes that can be marketed as characteristic of an overarching ethnic or, in Elias's case, regional identity.

In this way, the notion of "a" Kurdish, Turkish, Greek or else "culture" effectively produces what I want to call a fantasy of ethnic or national homogeneity. Local or regional differences may feature in such fantasies as colourful illustrations of variation within the body politic yet remain indexed to the larger whole (cf. Öztürkmen, 2001: 140-141). The term dengbêj testifies to the processes of erasure that the forging of a national cultural heritage involves. Argun Çakır (2011: 52) writes that this term, originally confined to the region of Serhed where it indicated singerpoets performing without musical accompaniment, has become an umbrella term that is today used to describe a wide variety of orally performed Kurdish traditions. Alternative regional terms to refer to singer-poets with repertoires or performance styles similar to the Serhedî dengbêjs, such as stranbêj or şair, on the other hand, 
have become increasingly marginalised. Given the prestige attached to the term dengbêj as the paradigmatic representative of authentic Kurdish tradition Çakır (2011: 52) reports that "some şair and stranbêj nowadays tend to drop these local performer designations, and call themselves dengbêjs."

Translated into a vocabulary of connections, we may say that the idea of a national cultural heritage acts as a mechanism that relates all individual cultural production directly to the overarching collective. This forms part of the dilemma that producers of ethnic art or world music face in global arenas, where they are recognized less for individual acts of artistic creativity than as representatives of an ethnic or national collective (Kosnick, 2007: 97). Inversely, this means that "culture" necessarily becomes the product of collective - and that is always also anonymous creativity. Modern copyright law reflects this assumption when it ascribes all intellectual creation for which no individual author comes forward to the public domain, thereby declaring it by default property of the undifferentiated collective of "the people" (Goodman, 2002: 89-91). What gets disavowed in this way are local and regional traditions reckoned through genealogical lines of transmission which trace certain cultural forms back through time to specific individuals or locations (cf. Glasser, 2016). In the past, the dengbêj tradition would have thrived on such genealogical reckoning of descent and epic ballads (kilam) firmly associated with the names of particular master dengbêjs still testify to these dynamics (cf. Hamelink, 2016). Contemporary forms of political representation and a modern culture industry, however, dictate a bifurcation along the lines of property between individual artists who own particular cultural products and a "culture" owned by the anonymous collective of "the people."

\section{Allegations of theft: Questioning the homogeneity of "the people"}

The elevation of dengbêjs to the paradigmatic producers and transmitters of an overarching "Kurdish culture," then, has gone hand in hand with the introduction of a logic of culture as property into this field of cultural production. Dengbêjs, it should be noted here, are primarily understood as masters of the kilam, a genre at the intersection of epic and lamentation. Described by the ethnomusicologist Estelle Amy de la Bretèque (2012, 137-143) as "melodized speech," kilams narrate non-fictional 
stories in a chant-like, recitative style. Many kilams are transmitted from dengbêj to dengbêj over generations, while others are newly crafted in order recount contemporary events and experiences. Previously communally owned and transmitted, logics of cultural property reconfigure kilams and similar oral traditions into objects that can be owned - either by individuals, or by collectives. Once objects can be owned, however, they may also be stolen. And indeed, while I did fieldwork I repeatedly witnessed anxieties about and allegations of theft, particularly on the part of the female dengbêjs I focused my research on. Such allegations provide valuable insight into the gendered contestations around kilams as ownable property. Let me first, however, provide some more information about the gendered dimensions of dengbêjî as a field of cultural production and performance.

The majority of my fieldwork centered on Van's Women Dengbêj Association. This association, founded in 2011 upon the personal initiative of Dengbêj Gazin - one of the few female dengbêjs to have entered the Kurdish music industry in Turkey was the first and only of its kind in Turkish Kurdistan at the time of my field research. Conceived by Gazin as a space where female singers and musicians would be able to socialize and support each other, the association managed to gather more than a dozen women dengbêjs, singers and musicians. Apart from providing a space where these women could sing and make music without being overheard by men, the association organized a number of concerts and arranged music classes for young girls and women. Shut down over a year ago due to financial difficulties, the significance of the association arguably lay in its attempt to organize Kurdish women singers publicly yet separately from men. Many of the women who came together at Van's Women Dengbêj Association had previously been part of the local NÇM, which had a special section for dengbêjs. Within this section, however, women were in the minority and, as Gazin told me, not taken seriously as singers by the male bards. The latter dominated public performances and relegated the women singers to the background.

The Women Dengbêj Association was founded in reaction to such experiences of gender-based discrimination at a Kurdish-run cultural institution. Yet these experiences also reflect long-standing practices widespread in Kurdish communities that have limited the ambit of women's voices to private and all-female domains. Particularly members of older generations often consider the audibility of women's 
(singing) voices in public shameful (serm) and potentially compromising of family honour, and therefore seek to restrict it. While this perception is changing - not the least due to the influence of the Kurdish political movement and its emphasis on gender equality - it has rendered women's voices less audible in public. It is not that Kurdish women are deprived of voice, but that their voices tend to circulate in private spaces, secluded from being overheard by strangers. One result is that the tradition of dengbêjî as a form of public oral history telling has largely been dominated by men, a situation that persists as dengbêjî has become integrated into cultural politics and the music industry.

The main exceptions to this trend only seem to confirm the rule. Meyrem Xan and Eyşe Şan, for instance - two of the earliest female dengbêjs who had their voices recorded in the nascent Kurdish music industry of the early twentieth century and who enjoy extraordinary fame and popularity amongst Kurdish audiences today - both experienced severe conflicts with their families over their public singing. Born in 1904 and married to a member of the famous Bedîrkhan family of Kurdish politicians and intellectuals, Meyrem Xan was forced to choose between her aspirations for a music career and her marriage, since her husband rejected her singing in public. She eventually divorced and in the 1930s moved to Baghdad, where she recorded with the Kurdish section of British-run Radio Baghdad until her death in 1949. A generation later, the dengbêj Eyşe Şan was equally rejected by her family for engaging in public singing. Faced at the same time with repressive Turkish state policies that censored Kurdish language and cultural expression, she was forced into exile after the 1971 coup d'état, first to Germany and later to Iraq, where she, too, realized recordings with Radio Baghdad. Both Meyrem Xan and Eyşe Şan's music reflects the emotional toll that familial rejection, exile, and loneliness had on them, and their kilams were highly popular amongst the women I encountered in early twenty-first-century Van. Gazin in fact often likened herself to Eyşe Şan, noting how similar her own struggles were to those of the famous dengbêj.

And indeed, the stories of the women I got to know through Van's Women Dengbêj Association bore important similarities with those of Meyrem Xan and Eyşe Şan. Most of my interlocutors had grown up in rural areas, where they had married early, looked after large families, and engaged in hard agricultural labour. Now most 
of these women were beyond child-bearing age, meaning they enjoyed a more powerful position within their kinship networks, which made engaging in cultural activism a lot easier. Yet almost all had stories to tell of severe conflicts they had lived in the past - some of them involving physical violence - with (often male) family members, who sought to prevent them from singing in public. Gazin herself was only able to do so since her father-in-law, the dominant patriarch of the family, had passed away. Not coincidentally, the most active women at the association were either widowed or had husbands who were absent for long periods of time or sick. Others had managed to convince their families that the attribution of shame to the female voice was inappropriate and did not befit "modern" and "civilized" Kurdish society, in doing so heavily drawing upon arguments regarding female emancipation as propagated by the Kurdish political movement.

Most of my interlocutors had acquired their knowledge of dengbêjî in childhood and adolescence through oral transmission from other dengbêjs (both male and female), radio broadcasts (particularly those of Radio Yerevan broadcasting from Armenia), and cassette tapes (often clandestine copies). The repertoire these women commanded was not radically different from that of male dengbêjs. In fact they often noted with pride that they knew the kilams of legendary male master dengbêjs such as Şakiro, Reso, or Karapetê Xaço and were able to perform them just as well as their male colleagues. Despite this emphasis on gender equity in terms of repertoire and performance, I noted that the kilams women composed themselves tended to focus on gendered themes, particularly gendered forms of suffering that Kurdish women regularly experience in their daily lives. Such kilams included, for example, pieces expressing a newlywed woman's loneliness when separated from her natal family after marriage, grief over the premature death of a child, or sadness over a failed romantic engagement. In this context it is important to note that the genre of the kilam is closely related to that of funeral lamentations (şin), with which it shares both textual and musical elements. Funeral lamentations, in turn, are generally performed by women, who are thus chiefly responsible for carrying out society's "work of pain” (Magrini, 2008).

Not only my interlocutors, but also male dengbêjs, cultural aficionados and musical practitioners repeatedly asserted that the genre of the kilam had developed out 
of funeral lamentations and that it was therefore a distinctly female genre. The women dengbêjs I worked with regularly invoked this idea to argue for the legitimacy of their quest to sing in public, and it is in these contexts that allegations of theft were brought forth. Aysel, a woman in her forties originally from the region of Şirnex (Şırnak), for instance, once put it that way: "Dengbêjî comes from women, from Kurdish women. Women used to sing most. All kilams that I know used to be sung by women. Women sang them but then men appropriated them. Men's voices came to be listened to by everybody, while the woman's voice remained secret. She could only sing at home, while putting her children to sleep, or outside where there were no men." Gazin similarly often complained that many of the kilams performed by male dengbêjs today had been "stolen" from women, who had created and used to sing them in an undefined past. In this way, she noted, men were able to accrue fame, status, and - in a growing Kurdish music industry - even financial gains that should in fact belong to women.

The narrative of dengbêjî as an originally female preserve that was over the course of history appropriated by men needs to be understood in the context of the Kurdish movement's own distinct historiography. According to the movement's account, Kurdish society in Neolithic Mesopotamia was matriarchally organized. This "original" period of matriarchy is seen as a golden age of natural socialism, during which hierarchical relations both inside and between communities were inexistent. The development of patriarchy, however, introduced the principle of hierarchy, which eventually led to the formation of the state and monotheist religions as the primary instruments of oppression. The demise of matriarchy thus connotes the fall of Kurdish society, its domination by patriarchal, feudal, and tribal structures and, in direct causal correlation, permanent political subordination (Açık, 2013: 119). Translated into the realm of dengbêjî, the narrative suggests that while this most authentic element of Kurdish culture was originally crafted and performed by women, with the "fall" of Kurdish society formerly powerful female dengbêjs were banned from the public, their voices branded as shameful and their works misappropriated by men.

Embedded within this broader historical narrative, then, the idea that men had misappropriated the art of dengbêjî from women was able to suggest that the restriction of women's voices through patriarchal notions of honour and shame 
constituted a historical mistake, as it were, and that women had all the right to take back what had unrightfully been taken away from them. Importantly, the kilams that women alleged men had "stolen" from them were often pieces that were commonly known as gelerî, a term that literally means popular but has come to denote anonymous in the context of music production. These were pieces, in other words, which circulated anonymously, were often orally transmitted and constituted part of a widely shared repertoire of Kurdish oral traditions. Claiming that women and not men were the actual yet misrecognised creators of this repertoire of anonymous folklore consequently also meant claiming that women and not men were the real holders and transmitters of Kurdish culture and tradition. In this vein, Gazin several times referred to women dengbêjs as the hidden "treasuries" (hazine) of Kurdish culture, implying that these treasuries urgently needed to be tapped in order to salvage the heritage they contained, before it would succumb to the pressures of political suppression and assimilation.

What I want to draw attention to here is the way in which the narrative of theft destabilizes the notion of a collectively produced and owned Kurdish cultural heritage. As outlined above, once culture is defined as property, ownership becomes a central category through which struggles over cultural production are expressed. When ownership over cultural products for which no individual artist is identifiable is attributed to the anonymous collectivity of "the people," moreover, the question of who is to legitimately represent this amorphous entity inevitably becomes a matter of debate. Within this framework, women dengbêjs' allegations of theft may be read as illustrating what is at stake when the ownership of prestigious cultural products is handed over to the allegedly undifferentiated entity of the people. Their claim that women and not men are the true producers and transmitters of dengbêjs' repertoires break up this ostensibly homogenous entity, exposing the hierarchies and struggles that traverse it (cf. Goodman, 2002). Put otherwise, we may say that women's allegations of theft represent acts of cutting the network of alleged collective cultural production; acts that are, moreover, specifically targeted at cutting out men from this collectivity.

\section{Cutting relations and channeling returns: Claiming individual ownership}


Apart from claiming collective ownership over Kurdish cultural heritage as women, some of my interlocutors also took up the second avenue that the culture as property logic offers, namely that of claiming individual ownership. During my fieldwork encounters, the women I interviewed often felt a need to highlight that a certain kilam or folk song they were telling me about "was theirs" (-ya min e). Yet such claims did not prevent them from acknowledging in the same breath the genealogies through which they had acquired their knowledge of these pieces. That is to say, they fully acknowledged that the pieces they claimed "were theirs" were also part of a broader repertoire of oral traditions widely shared throughout Kurdish geographies. Such instances represent, I suggest, ambiguous moments of concurrence and intersection between genealogical ways of claiming belonging and the logic of individual ownership that newer models of cultural property provide. Following Marilyn Strathern (1996b), we may conceptualize the latter as requiring individuals to perform acts of truncating relations between their own works and others in order to make claims to ownership legitimate. The repertoires that dengbêjs routinely perform, however, do not lend themselves easily to such truncating. Claims to individual ownership on the part of dengbêjs, I argue, therefore take the shape of a delicate labour of negotiation between acknowledging and disavowing connections.

What is it about dengbêjs' repertoires that renders acts of cutting in the name of individual ownership difficult? Here it is useful to distinguish between folk songs and kilams that have been transmitted over long periods of time, usually orally, without attribution to a particular author (i.e. pieces that are deemed anonymous or gelerî) and "new" (for lack of a better word) kilams which individual dengbêjs have crafted themselves in order to recount a particular event in the present or near past. The former lend themselves more easily to the kind of collective claims of ownership on the part of women that I describe above. These are pieces that are clearly inscribed in broader networks of oral and musical exchange and contact, which my interlocutors would take great pleasure to explore. I hence observed at several occasions how female dengbêjs who encountered each other at the Women Dengbêj Association, concerts, or other cultural events would compare and contrast at great length the different versions of folk songs and kilams they knew. They would happily spend hours performing for each other the same piece in different variations and debate in 
depth about which version might be the correct one.

Such conversations were marked by the conviction that one or other version ought to be more "correct" (rast) or true to the "original" (orijinal) version of a piece, the latter presumably a sort of ur-version of a song at its moment of creation before it started its journey of oral transmission over the generations. Most times such debates would end without resolution, with each woman proudly asserting that the way she knew the song in question was the correct one. This conviction of knowing a piece correctly (which might concern both textual and musical elements) would repeatedly translate into an assertion of belonging or ownership of the kind "This song is mine (Ev ya min e)!" The sense that a particular kilam or folk song "was theirs," then, entailed less a disavowal of the connections making up a branched-out and widely connected collective repertoire than the assertion of knowledge of "true" form and content. As such, claiming ownership entailed cutting out others from the true and correct knowledge of the intricacies of a widely dispersed repertoire.

The assertion of ownership over kilams which some of my interlocutors had crafted themselves might appear a more straightforward matter by contrast. These were kilams, after all, that recounted my interlocutors' personal experiences, thoughts and sorrows. Emerging out of women dengbêjs' attempts at giving testimony to personal experience by means of language and music, these were not the anonymously transmitted songs that circulate widely across Kurdistan but products of an identifiable individual's creativity. Yet as much as these pieces might have been "new" with regards to what they recounted (for example an event like the Van earthquakes of 2011, or a women's personal pain over having lost a loved one) the lyrical and musical form they took drew heavily upon a pool of poetic expressions and melodic elements widely shared across kilams and other oral genres such as epics, fictional stories, or fairy tales.

Take, for example, Gazin's kilam about the Van earthquakes of 2011, of which I reproduce a stanza below. In order to show the extent to which even "new" kilams draw upon established textual themes, I have marked elements that can frequently be found in other kilams and oral genres in bold. 


\begin{tabular}{|c|c|}
\hline $\begin{array}{l}\text { Dewrane, dewrane, dewrane, dayê li } \\
\text { min bûye dîsa dewrane }\end{array}$ & $\begin{array}{l}\text { These are bad times, bad times, bad } \\
\text { times, mother once again these are } \\
\text { bad times for me }\end{array}$ \\
\hline $\begin{array}{l}\text { Berê vê payîzê min ê ji xwe re kirî kar û } \\
\text { barê }\end{array}$ & $\begin{array}{l}\text { Before this fall I occupied myself with } \\
\text { craft and trades }\end{array}$ \\
\hline $\begin{array}{l}\text { Vê zivistanê li ser serê me digeriya } \\
\text { ewrekî reş û tarî, ewrê erdhejane }\end{array}$ & $\begin{array}{l}\text { This winter a dark black cloud hovered } \\
\text { above us, the cloud of earthquakes }\end{array}$ \\
\hline $\begin{array}{l}\text { Dema min ê bala xwe lê dida Erdîşê } \\
\text { Wanê, temame bi gundane }\end{array}$ & $\begin{array}{l}\text { When I turned towards Erdîş and Wan } \\
\text { and all its villages }\end{array}$ \\
\hline $\begin{array}{l}\text { Wele dîsa bûye fermane, fermana } \\
\text { erdhejane, dayê dewrane }\end{array}$ & $\begin{array}{l}\text { Oh God, a verdict again, the verdict } \\
\text { of earthquakes, mother these are bad } \\
\text { times }\end{array}$ \\
\hline $\begin{array}{l}\text { Min ê bala xwe didayê xanî û malane, } \\
\text { zarîn têtin zarokane, hewar têtin dayik û } \\
\text { babane, qerîn têtin mamostane, dayê li } \\
\text { min bûye fermane }\end{array}$ & $\begin{array}{l}\text { I turned towards homes and houses, I } \\
\text { heard the wailing of children, the cries } \\
\text { of mothers and fathers, the shouts of } \\
\text { teachers, mother this is a verdict upon } \\
\text { me }\end{array}$ \\
\hline $\begin{array}{l}\text { Wê di min got dewrane, dewrane, } \\
\text { dayê dîsa li min bûye fermane, } \\
\text { fermana erdhejane, dayê dewrane }\end{array}$ & $\begin{array}{l}\text { I said these are bad times, bad times, } \\
\text { mother once again a verdict upon me, } \\
\text { the verdict of earthquakes, mother } \\
\text { these are bad times }\end{array}$ \\
\hline $\begin{array}{l}\text { Wî di şûna axîn û nalînê wan name yaz } \\
\text { kirine, xistine berîka wane, torbe tijî } \\
\text { kirine bi kevirane, ji wan re şandine, } \\
\text { dibê: 'Ev heqê wan Kurdan e.' Dayê } \\
\text { dewrane, dayê dewrane }\end{array}$ & $\begin{array}{l}\text { Instead of crying and wailing they sent } \\
\text { letters, put them in their pockets, filled } \\
\text { up bags with stones, and sent those to } \\
\text { them, saying: 'This is what the Kurds } \\
\text { deserve.' Mother these are bad times, } \\
\text { bad times }\end{array}$ \\
\hline $\begin{array}{l}\text { Wî de dewrane, dewrane, dewrane, } \\
\text { dayê li min bûye fermane }\end{array}$ & $\begin{array}{l}\text { Bad times, bad times, bad times, } \\
\text { mother once again a verdict upon me }\end{array}$ \\
\hline
\end{tabular}

As the above illustrates, nearly half of the stanza's lyrics is composed of recurrent 
textual elements, these being mainly the poetic motifs that lend the account its emotional and affective impact. Their arrangement throughout the kilam, preceding and following sections that recount the events of the earthquake in more factual terms, suggests that these motifs function quite literally like brackets which emotionally frame the account and in this way insert this personal - and in many ways highly political - testimony into a longstanding genealogy of tragic accounts transmitted by dengbêjs.

Even though Gazin had in a sense "borrowed" a large part of her kilam's lyrics from a communal pool of textual motifs and set them to a well-known meqam, she considered this kilam not only her own but also proceeded to legally instate that ownership by claiming copyright over the kilam. She had it registered under her name at the Professional Union of Owners of Musical Works (Musiki Eseri Sahipleri Grubu Meslek Birliği, MSG), one of Turkey's two principal institutions managing musicians' copyright claims, alongside a dozen other kilams and folk songs she also considered her own. Gazin was the only female dengbêj amongst those I encountered who took this step. I nevertheless deem her initiative important because it speaks of a readiness to cut networks much more radically than might have been the case in the past.

What is at stake, I suggest, is a potentially quite profound change in how connections are reckoned within a musical tradition such as dengbêjî. This is a tradition in which connections between musical works would in the past have been traced through personal and geographical genealogies. That is to say, kilams would have been transmitted orally when dengbêjs encountered each other during the mainly male gatherings in the houses of village headmen or in the teahouses of Kurdish towns, when women sang songs together while herding livestock or engaged in housework, or yet again when they listened to the Kurdish broadcasting hours on Radio Yerevan, played cassette tapes with Kurdish music recordings that had been smuggled clandestinely across the Iraqi or Syrian borders, or tuned into one of the Kurdish satellite TV stations. Some of the kilams transmitted in this way would be associated with particular personalities recognised either as these kilams' authors or as their most important performers. Other kilams or folk songs might be identified less with a specific personality than with a certain region. Inscribed in such personal and geographical genealogies, kilams and folk songs were nevertheless free to circulate 
and open to communal use, that is, they were free to be performed by anybody skilled enough to do so. At the same time, this communal repertoire also constituted an important resource of "building blocks" for the assemblage of kilams recounting previously untold events and experiences, as we saw in the case of Gazin's kilam above.

Registering certain kilams as the personal property of individual artists through copyright arrangements will certainly not prevent ordinary Kurdish women and men from continuing to share and transmit oral traditions, even if these are legally speaking now another's property. Yet what the readiness to appeal to copyright legislation speaks of, I believe, is a willingness to channel any returns that the circulation of such traditions might accrue - be it in the form of authority, fame, or financial profit - much more adroitly towards the individual artist. The latter in this way becomes the start and end point of circulation, in a logic rather different from the tracing of genealogical lines of alliance and descent that would distribute returns more broadly.

Indeed, the women I worked with were convinced that large profits could be accrued in the music industry, and this conviction certainly constituted a key motivation for Gazin to formally claim copyright. Yet this conviction came with a sense of exclusion: considering themselves to be the real owners of Kurdish cultural heritage they felt that others - successful male dengbêjs, for example, but also male and female Kurdish pop singers whose success thrived on their adaptation of traditional folk songs for the popular music market - were making a profit out of what actually belonged to them. Gazin herself was one of the few female dengbêjs of her generation who had successfully entered the music industry and she could proudly count a dozen albums featuring kilams and folk songs as her own. Her male producers, however, had never paid any royalties to her even though some of her albums became best sellers, taking advantage of the fact that Gazin was illiterate, largely unfamiliar with the workings of the music industry, and unaware of her own rights and entitlements when her producers first discovered her.

The context of an emerging music industry and the way in which it distributes financial profits along relations of property rather than genealogical lines of transmission thus represents a central mechanism in the carving up of communally 
owned, transmitted and utilized repertoires into domains of individual ownership. The latter necessarily relies on cutting or disavowing relations that could potentially challenge the sovereignty of the individual artist over his or her work. Yet as I have tried to show, this cutting of relations is an ambiguous, laborious and above all contested process given that the repertoires which dengbêjs master are not necessarily conducive to such cutting. Kilams and folk songs are steeped in a genealogical ethos that makes it difficult to disavow their shared character and constant transformation through repeated performance.

\section{Conclusion}

The seemingly paradoxical statements with which I opened this chapter testify to how women dengbêjs seek to negotiate the fragmented terrains of contemporary Kurdish cultural production. Saturated with promises of authority, fame, and financial profit, these terrains are highly contested. Gender, as we have seen, represents one of the key faultlines in ongoing struggles over promised returns. Such struggles are centrally fuelled by a logic of culture as property and the ways in which it validates as eligible owners of cultural products individual artists, on the one hand, and anonymous collectives such as "the people," on the other hand. Both these forms of ownership radically reconfigure - though each in different ways - how connections and exchange are reckoned within networks of cultural production. While logics of individual authorship entail a cutting or arresting of genealogically reckoned relations of transmission, the notion of cultural heritage risks erasing local and regional variations in favour of an overarching popular or national culture.

But the capitalist logics of property inscribed in modern state institutions do not simply erase local and regional ways of reckoning relations of transmission and descent. What I am telling is hence not a linear story of the inevitable demise of tradition, a story that might be read with either nostalgia or triumphalism, depending on one's perspective. Rather, what I have tried to show is how women dengbêjs mobilize different logics of tracing connections in ways that are not always coherent or straightforward. Yet it is in and through the resulting friction, to use a term coined by anthropologist Anna Tsing (2004), that oral traditions are practiced in Turkish Kurdistan today. 


\section{Acknowledgements}

Research for this article and writing were funded by fellowships from the German Academic Scholarship Foundation, Trinity Hall College, the Wiener-Anspach Foundation, the Orient Institute Istanbul and the Research Foundation Flanders. I wish to thank the editors of this volume for their generous comments and feedback on earlier versions of this article. I also thank my interlocutors and friends in Turkey, whose generosity and support have made this work possible.

\section{References}

Amy de la Bretèque, E. (2012) Voices of sorrow: melodized speech, laments, and heroic narratives among the Yezidis of Armenia. Yearbook for Traditional Music, 44, 129-48.

Açı, N. (2013). Re-defining the role of women within the Kurdish national movement in Turkey in the 1990s. In C. Gunes \& W. Zeydanlioglu (Eds.). (2013). The Kurdish Question in Turkey: New Perspectives on Violence, Representation and Reconciliation, (114-135). Oxon: Routledge.

Aksoy, O. E. (2006). The politicization of Kurdish folk songs in Turkey in the 1990s. [Electronic version] Music and Anthropology: Journal of Musical Anthropology of the Mediterranean, 11 .

Blum, S., \& Hassanpour, A. (1996). 'The morning of freedom rose up': Kurdish popular song and the exigencies of cultural survival. Popular Music, 15(3), 325-343.

Çakır, A. (2011). The Representation of the Dengbêj Tradition in Kurdish Contemporary Popular Discourse. (Unpublished M.A. thesis). University of Exeter, Exeter.

Elias, N. (2016). This is not a festival: transhumance-based economies on Turkey's upland pastures. Nomadic Peoples, 20, 265-286.

Fuccaro, N. (2003). Kurds and Kurdish nationalism in mandatory Syria: politics, culture and identity. In A. Vali (Ed.). (2003). Essays on the Origins of Kurdish Nationalism, (191-217). Costa Mesa: Mazda.

Glasser, J. (2016). The Lost Paradise: Andalusi Music in Urban North Africa. Chicago: University of Chicago Press.

Goodman, J. E. (2002). "Stealing our heritage?": women's folksongs, copyright law, and the public domain in Algeria. Africa Today, 49(1), 85-97.

Hamelink, W. (2016). The Sung Home: Narrative, Morality, and the Kurdish Nation. Leiden: Brill.

Karaca, B. (2011). Images delegitimized and discouraged: explicitly political art and 
the arbitrariness of the unspeakable. New Perspectives on Turkey, 45, 155-183.

Klein, J. (2000). Proverbial nationalism: proverbs in Kurdish nationalist discourse of the late Ottoman period. The International Journal of Kurdish Studies, 14(1/2), $7-26$.

Kosnick, K. (2007). Migrant Media: Turkish Broadcasting and Multicultural Politics in Berlin. Bloomington: Indiana University Press.

Magrini, T. (2008) Women's “work of pain” in Christian Mediterranean Europe. [Electronic version] Music \& Anthropology: Journal of Musical Anthropology of the Mediterranean 3.

Öztürkmen, A. (2001). Politics of national dance in Turkey: A historical reappraisal. Yearbook for Traditional Music, 33, 139-43.

Reigle, R. F. (2013). A brief history of Kurdish music recordings in Turkey. [Electronic version] Hellenic Journal of Music, Education, and Culture, 4(1).

Scalbert-Yücel, C. (2009). The invention of a tradition: Diyarbakır's dengbêj project. [Electronic version] European Journal of Turkish Studies, 10.

Schäfers, M. (2015). Being sick of politics: the production of dengbêjî as Kurdish cultural heritage in contemporary Turkey. [Electronic version] European Journal of Turkish Studies, 20.

Strathern, M. (1996a). Cutting the network. Journal of the Royal Anthropological Institute, 2(3), 517-535.

Strathern, M. (1996b). Potential property: intellectual rights and property in persons. Social Anthropology, 4(1), 17-32.

Strohmeier, M. (2003). Crucial Images in the Presentation of a Kurdish National Identity: Heroes and Patriots, Traitors and Foes. Leiden: Brill.

Tambar, K. (2014). The Reckoning of Pluralism: Political Belonging and the Demands of History in Turkey. Stanford: Stanford University Press.

Tsing, A. L. (2004). Friction: An Ethnography of Global Connection. Princeton: Princeton University Press.

Viejo-Rose, D., Isar, Y. R., \& Anheier, H. K. (2011). Introduction. In H. Anheier \& Y. R. Isar (Eds.). (2011). Cultures and Globalization: Heritage, Memory and Identity, (1-20). London: Sage Publications.

Watts, N. F. (2010). Activists in Office: Kurdish Politics and Protest in Turkey. Seattle: University of Washington Press.

Yüksel, M. (2010). Dengbêj, Mullah, Intelligentsia: The Survival and Revival of the Kurdish-Kurmanji Language in the Middle East, 1925-1960. (Unpublished doctoral dissertation). University of Chicago, Chicago. 